RESUME METERI HUKUM TATA NEGARA

Nama : : Syahrul Muarif

Nim $\quad: 10200120210$

Pembahasan :

\title{
Hukum Tata Negara
}

\section{Pengertian}

Hukum Tata negara atau HTN Adalah salah satu cabang ilmu hukum dimana objek kajiannya ialah negara, terkait mengatur dan menata negara dalam artian organ dan lembaganya.

Pengertian Hukum tatanegara secara Terminologi yakni

- Inggris : Constitutional law

- Belanda : Statrcht Terbbagi dua:

a).In Rumiere sin (Ivas) (Htn dan Han)

b).in enggere zin (Sempit) Htn

- Prancis :

a).Drioit Constitutional -) Htn

b).Drioit Administratif -)Han

- Jerman :

a).Verfasungrecht

b).verwassung recht

- Indonesia : Dalam arti sempit merupakan Negara dalam keadaan diam wewenang dengan ini Struktur dan jabatan.

Berbagai pendapat mengenai definisi hukum tata negara dan tentu menimbulkan perbedaan antara satu sama lain. Hal ini pada dasarnya tidak terlalu signifikan untuk diperdebatkan.Dan berdasarkan berbagai pendapat itu, kita dapat melihat beberapa perbedaan dan persamaan pendapat. Sehingga, pengertian Hukum Tata Negara dapat dikatakan bahwa hukum tata negara merupakan sebuah peraturan yang mengatur mengenai penyelenggaraan pemerintahan yang dijalankan oleh pejabat atau alat alat negara/ Lembaga negara. 


\section{Ruang Lingkup HTN}

- Lembaga Negara

- Konstitusi

- Bentuk dan sistem pemerintahan

- Batasan dan pemisahan kekuasaan

- Hak Asasi Manusia

- prinsip dan hubungan antar negara

\section{Hubungan HTN dengan ilmu lainnya}

\section{Hukum Administrasi negara}

Sebenarnya tidak cukup jauh dengan ilmu negara dan HTN sama-sama soal negara tetapi hubungan antara HTN dan HAN adalah HTN mengatur persoalan fungsi dan wewenang negara baik secara horizontal dan vertikal sementara HAN mengatur persoalan bagaimana cara menggunakan wewenang dan fungsi tersebut.

\section{* ilmu politik}

Politik dan ADN adalah sama-sama mengatur persoalan kekuasaan negara hanya saja ilmu politik mengkaji persoalan apa-apa saja yang dapat mempengaruhi setelah ditentukan model kekuasaannya oleh HTN .

\section{Sumber Hukum Tata Negara}

\section{- Sumber hukum materil}

Sumber hukum materiil adalah tempat dimana diambilnya sumber hukum materiil misalnya Pancasila, norma agama, kesusilaan. Sumber hukum materiil harus ada dalam setiap hukum formil. Ia harus menjiwai dan harus dilaksanakan sebagaimana mestinya.

\section{- Sumber hukum formil}

Sumber hukum formil dalam hukum tata negara adalah sumber hukum yang sudah diundangkan. misalnya, undang-undang dasar Negara republik Indonesia tahun 1945, peraturan perundang undangan, yurisprudensi, konvensi ketatanegaraan, dan traktat serta doktrin.

1. Undang-undang dasar adalah norma dasar dari sebuah negara untuk bergerak yang telah dikodifikasi dalam satu buku.Sementara peraturan undang-undang terdiri atas ketetapan MPR, PERPU, Peraturan pemerintah, sampai pada peraturan desa dan dalam hierarki nya tidak boleh bertentangan satu sama lain. 
2. Yurisprudensi, Yurisprudensi biasanya dikenal di Negara dengan sistem hukum common law tetapi dengan seiring berjalannya waktu negara-negara civil law mulai menganutnya misalnya Indonesia. Yurisprudensi berupa putusan hakim terdahulu yang digunakan menjadi sumber hukum dalam kasus yang sama.

3. Konvensi, Konvensi adalah kebiasaan-kebiasaan atau kelaziman dalam praktik bernegara yang dianggap penting dan baik untuk berjalannya sebuah negara maka dengan itu ia dijadikan sumber hukum.

4. Traktat, Traktat adalah perjanjian internasional yang diadakan oleh dua atau lebih negara. Perjanjian internasional terbagi atas dua yaitu bilateral dan multilateral. Bilateral adalah perjanjian yang diadakan oleh dua negara saja. Sementara multilateral adalah perjanjian yang diadakan oleh lebih dari dua negara.

5. Doktrin, Doktrin adalah pendapat dari para ahli atau pakar hukum yang dijadikan sebagai sumber hukum karena para pakar hukum tersebut dinilai berkompeten dan berintegritas dalam bidang hukum tata negara misalnya.

\section{Asas-asas hukum tata negara}

\section{- Asas Pancasila}

Dalam sejarah Indonesia Pancasila telah disepakati sebagai dasar negara maka dari itu segala tindakan dari penyelenggara negara tidak boleh menyimpang dari apa yang kemudian dicita citakan oleh Pancasila itu sendiri.

\section{- Asas Negara Hukum}

Dalam undang-undang dasar negara republik Indonesia tahun 1945 pasal 1 ayat 3 yang menjelaskan bahwa negara Indonesia adalah negara hukum. Maksudnya adalah segala penyelenggara negara baik itu tindakan dari aparatur maupun warga negaranya harus berdasarkan dan tunduk pada hukum.

\section{- Asas Negara Kesatuan}

Pasal 1 ayat 1 undang-undang dasar Negara republik Indonesia tahun 1945 mendudukkan dengan tegas bahwa negara Indonesia adalah negara kesatuan yang berbentuk republik. Maka dari itu seluruh tindakan sikap dan kebijakan dari negara ataupun pemerintahan negara harus sesuai dengan prinsip kesatuan untuk menjaga persatuan Indonesia. Yang artinya tidak boleh mengandung diskriminasi oleh satu atau lebih daerah.

\section{- Asas kedaulatan rakyat dan demokrasi}

Pasal 1 ayat 2 undang-undang dasar Negara republik Indonesia tahun 1945 menerangkan bahwa kedaulatan berada ditangan rakyat dan dilaksanakan menurut undang-undang dasar. Maksudnya adalah seluruh penyelenggara negara baik itu pembayaran kebijakan ataupun peraturan maupun hukum dari negara harus sesuai dengan kehendak rakyat dan tetap menjunjung tinggi hak asasi manusia dari warga negara. 


\section{- Asas pemisahan kekuasaan dan check and balance}

Asas pemisahan kekuasaan pertama kali diperkenalkan oleh John Locke yang disempurnakan oleh montesquieu dengan keresahan atas absolutisme. Pemisahan kekuasaan dibagi atas tiga bidang yaitu eksekutif legislatif dan yudikatif dengan itu diharapkan penyelenggaraan negara bisa saling melakukan check and balance antar sesama lembaga negara saling mengontrol juga sehingga peluang terjadinya penyalahgunaan kekuasaan dapat diminimalisir.

\section{Sejarah Ketatanegaraan}

Sampai sekarang, permasyarakatan UUD 1945 pasca perubahan keempat relative masih sangat terbatas. Padahal isinya telah mengalami perubahan lebih dari 300 persen. Sebagai gambaran, sebelum diadakan perubahan, ketentuan yang terkandung didalamnya menjadi 199 butir. Namun, sebagai akibat perubahan yang sangat mendasar dan bersifat besar-besaran Konstitusi adalah hukum dasar yang dijadikan acuan/atau pedoman dalam penyelenggaraan suatu negara. Sebagai hukum dasar konstitusi dapat berbentuk hukum dasar yang tertulis dan dapat pula tidak tertulis. Indonesia menganut konstitusi tertulis yang disebut dengan undang undang dasar titik sejarah ketatanegaraan Indonesia telah beberapa kali mengalami pergantian dimulai dari UUD 1945,konstitusi RIS, UUD sementara, dan akhirnya kembali ke UUD 1945 lalu kemudian mengalami perubahan pada tahun 1999, 2000, 2001, dan tahun 2002.

\section{- UUD 1945}

Resmi berlaku, UUD 1945 belum sepenuhnya menjadi rujukan dalam penyelenggaraan negara di belakang menurut jimly keberadaan UUD saat itu hanya dijadikan alat untuk menguatkan status Indonesia sebagai sebuah negara dan memang UUD 1945 juga masih bersifat sementara

\section{- Konstitusi RIS}

Hasil KMB tersebut, disusunlah naskah UUD dan disepakati oleh kedua pihak dengan nama Undang-undang dasar republik Indonesia serikat atau yang dikenal dengan istilah konstitusi RIS.Naskah konstitusi RIS kemudian diserahkan kepada KNPI dan disetujui oleh KNPI pada tanggal 14 Desember 1949, dan secara resmi mulai diberlakukan pada tanggal 27 Desember 1949, sekaligus menjadi akhir dari berlakunya undang-undang 1945, seperti halnya UUD 1945 konstitusi RIS juga masih bersifat sementara hal tersebut dapat dilihat pada ketentuan pasal 186, yang menegaskan bahwa konstituante bersama-sama dengan pemerintah selekas-lekasnya menetapkan konstitusi republik Indonesia serikat.Undang-undang dasar sementara 1950.Negara ris tidak bertahan lama. Negara republic Indonesia,negara Indonesia timur, dan negara sumatera timur menggabungkan diri menjadi satu wilayah republic Indonesia. 19 mei 1950 pemerintah RIS dan pemerintah RI sepakat membentuk kembali NKRI dibentuk panitia untuk merancang UUD. Perubahan RIS menjadi UUDS yang resmi berlaku 17 agustus 1950 dengan UU Faderal no. 7 tahun 1950. Dasarnya yaitu pasal 134 UUDS : konstituante Bersama pemerintah menyusun suatu uud ri yang akan mengganti uud 1950. 


\section{- Pemilihan umum 1955 : memilih konstituante}

Dalam waktu 3 tahun yakni 1956-1959 konstituante berhasil merumuskan sejumlah pasal, tapi mengalami kebuntuan dalam dasar negara. Desember 1955 pemilu memilih konstituante untuk mmebentuk UUD. 1956-1959 konstituante bersidang dengan maksud membua UUD yang tetap.

\section{Konstitusi sebagai objek kajian hukum tata negara}

Dalam ketatanegaraan istilah konstitusi di berbagai negara telah banyak dipergunakan. Misalnya di belanda 'Contitutie' disamping kata 'ground wet' inggris 'constitution' dalam istilah sehari-hari konstitusi sering disamakan dengan undang-undang dasar yang merupakan terjemahan dari groundwet dalam Bahasa belanda (griund artinya dasar, wet artinya undang undang).Konstitusi itu lebih luas dari UUDPengertian ini dikemukakan oleh Herman Heller dalam bukunya ajaran kostitusi sebagaimana dikutip oleh Moh. Koesnardi dan Bintan saragih (1994:140-1941) yang membagi konstitusi dalam 3 tingkat, yaitu :

- Konstitusi sebagai pengertian sosial politik

- Konstitusi sebagai pengertian hukum

- Konstitusi sebagai suatu peraturan hukum, yakni peraturan hukum yang tertulis

\section{Organ dan fungsi kekuasaan negara}

Istilah pemisahan kekuasaan itu sendiri konsep yang bersifat umum, seperti halnya konsep pembagian kekuasaan juga dipakai oleh banyak sarjana dengan pengertian-pengertian yang berbeda-beda satu dan yang lain. Arthur Mass membedakan pengertian pembagian kekuasaan tersebut kedalam dua pengertian yaitu capital divisionof power, dan territorial division power, pengertian yang pertama bersifat fungsional, sedangkan yang kedua bersifat kewilayahan atau kedaerahan. Dengan demikian dapat dibedakan penggunaan kekuasaan itu dalam dua konteks yang berbeda, yaitu kekuasaan horizontal dan vertical.Dalam teori pembagian kekuasaan oleh montesquieu menjelaskan bahwa perlu tiga pembagian kekuasaan di antaranya adalah eksekutif legislatif dan yudikatif hal ini bertujuan untuk membedakan secara tegas atau secara terperinci fungsi dari ketiga lembaga negara tersebut serta untuk memenuhi fungsi check and balance atau fungsi kontrol dan keseimbangan antar warga negara tersebut.

\section{- Kekuasaan legislatif}

Kekuasaan legislatif memiliki 3 fungsi yaitu fungsi legislasi atau fungsi pengaturan kemudian fungsi pengawasan dalam hal mengawasi perumusan dan penentuan kebijakan dari pemerintahan dan yang terakhir adalah fungsi anggaran yaitu untuk menentukan 
pelaksanaan anggaran negara dengan berbagai pertimbangan dan beberapa ahli untuk hal tersebut

- Kekuasaan eksekutif

Kekuasaan eksekutif biasa dikenal sebagai pelaksana kebijakan dari kekuasaan legislatif biasanya kekuasaan eksekutif ini diduduki oleh presiden wakil presiden serta jajaran kementerian.

- Kekuasaan Yudikatif

Kekuasaan yudikatif dengan sistem peradilan yang independen hal ini bertujuan untuk tetap menjaga hak asasi manusia yang telah dicantumkan dalam konstitusi Indonesia. Dalam proses bekerjanya kekuasaan yudikatif dilaksanakan oleh mahkamah Agung dan mahkamah konstitusi serta pengadilan turunannya misalnya pengadilan tinggi, pengadilan negeri dan beberapa pengadilan yang bersifat khusus misalnya pengadilan anak, pengadilan Tipikor dan pengadilan pajak. 